\title{
Children's Rights Ombudsman, Efficient Defense Mechanism
}

\author{
Margarita Cheshmedzhieva ${ }^{1}$ \\ ${ }^{1}$ Public Law and Public Management Department, Law and History Faculty, South-West University "Neofit \\ Rilski”, Blagoevgrad, Bulgaria \\ Correspondence: Margarita Cheshmedzhieva, Public Law and Public Management Department, Law and History \\ Faculty, South-West University "Neofit Rilski", 2700 Blagoevgrad, Georgi Izmirliev-Macedoncheto1 Sq., \\ Bulgaria. Tel: 359-7383-3208. E-mail: margo4@abv.bg
}

\author{
Received: February 26, 2015 Accepted: April 1, 2015 Online Published: May 27, 2015 \\ doi:10.5539/jpl.v8n2p137 URL: http://dx.doi.org/10.5539/jpl.v8n2p137
}

\begin{abstract}
The article provides a comparative legal analysis of the specialized institution "Children's Rights Obmudsman", as a mechanism for the protection of minors, established in many democratic countries.

The author's objective is to prove the necessity of such an institution, based on the comparative analysis, because children are the most unprotected and vulnerable group of the population. The focus is on that, because the protection of the rights and interests of minors, who form the future of the nation, should be a top priority in the activities of each Government.

An independent mechanism is required for their protection and for ensuring their rights, protecting them from exploitation, cruelty and indifference on the part of the society, especially with respect to the children without parents. This institution must focus its activity, exclusively on the protection of the rights and interests of children.

The establishment of such an institution serves not only the purpose of evidencing Government's obligation to ensure children's rights, but also the readiness to assume responsibility for fulfilling that obligation.
\end{abstract}

Keywords: ombudsman, children rights protection, vulnerable social groups

\section{Introduction}

An important priority for each rule and democratic state must be protecting the rights and interests of minors and the underage citizens. This is caused by the fact that children are the most vulnerable and least experienced members of the public who are not able to defend their own interests, which most closely refers to the children left without parental care, children with disabilities and children living in different social houses.

Children are especially vulnerable when they have to assert their rights because they do not have the ability to independently use the influence of the institutions which are to take the necessary measures and changes. Moreover, very often children, due to their inexperience, cannot take advantage of existing mechanisms for protection: appealing in court, complaints to the public administration, etc.

Children's rights are more endangered than adults' ones since they cannot defend themselves, because considering their age, mental, physical and intellectual development, and due to their limited capacity, they cannot contact the competent authorities in order to protect their rights and legitimate interests.

Experience shows that children have limited use of the existing mechanisms for protection in comparison with adults. That is the reason why it is necessary to create additional mechanisms for protection of the children's rights and interests.

That is the reason why it is necessary to create additional mechanisms for protection of the children's rights and interests.

At an international level, there are a number of instruments that have been adopted and dedicated to the rights of the child, which enable protection. Such international instruments include the UN Convention on the Rights of the Child (Convention on the Rights of the Child, adopted by the UNGA on 20.11.1989., Ratified by the Republic of Bulgaria in 1991), the Geneva Declaration on the Rights of the Child, 1924, and the Declaration on the Rights of the Child adopted by the General Assembly in 1959 and recognized in the Universal Declaration of 


\section{Human Rights.}

The legal basis of the specialized ombudsman for children's rights protection is precisely the United Nations Convention on the Rights of the Child, although the creation of such an institution is not mentioned directly in it. It provides for the creation of specific mechanisms for ensuring children's rights such as the particularly specialized ombudsman for children's rights. Even though the Convention has been ratified by many countries, a few of them have already created a specialized ombudsman institution for children's rights protection.

\section{Main features of the Children Rights Ombudsman}

The specialized institution ombudsman covers a particular sector, region or issue of governance. The specialization of the Ombudsman is determined by the necessity to increase the effectiveness of the activity of the Ombudsman in a narrower sphere.

When we say specialized ombudsman, we mean an independent public institution established to protect the rights and legitimate interests of people belonging to vulnerable social strata and groups, as well as their observance by government bodies and local self-government bodies as well as local administration.

The specialized ombudsman institutions function simultaneously with the ombudsman institutions with general competence. Acting within its jurisdiction, the specialized ombudsman investigates cases of discrimination, violated rights and legitimate interests of individuals from these groups or the group as a whole.

The main function of the specialized ombudsman institutions is connected not only with the restoration of the violated rights of the applicant, but also with the government's policy towards vulnerable social groups or towards the certain area of public relations referring to its jurisdiction.

The specialized ombudsman for children's rights was established as an additional protective mechanism that helps to improve the legal protection of minors, and as well as to make their needs and interests more evident for the institutions and the society as a whole.

The establishment of such an institution serves not only as evidence for the government's obligation to protect children's rights, but also its willingness to take responsibility for the complying with this obligation.

The ombudsman for the protection of children must exercise control over the bodies for custody and guardianship, organizations and institutions for education, health and social services. Particular attention should be paid to the legal explanation of children's rights and mechanisms for their protection.

The ombudsman may hold certain public powers, for example, with regard to parents who do not comply with their obligations for the upbringing and education of children or abuse their parental rights. This is necessary because children are such a legal entity that does not have the right to defend their own interests. It should be accessible to children and it should focus its activities on their problems (Flekkoy, 1990).

The ombudsman for children's rights protection needs to have appropriate powers to effectively carry out its functions, and independently to determine the directions of its activity. Its powers should refer mainly to:

- Carrying out investigations in specific cases. It carries out inspections independently or together with government bodies for violations of children's rights;

- Its right to visit government bodies and local self-government bodies and local administration and it is essential that the visit to children's institutions is smooth;

- Preparation of proposals for amendments to existing legislation on issues affecting children's rights;

- Making the competent officials proposals and recommendations related to securing the rights of children and improving the procedures related to the rights of children;

- The ombudsman in its work establishes expert groups which consist of professionals working with children.

\section{The Children Rights Ombudsman in European Countries}

In many countries throughout Europe and Latin America, in Australia and Canada specialized offices of children's rights ombudsman are established. In some of them this institution is based on a national level, and in others - on regional.

In every country in which there is a specialized ombudsman of this type the institution is established, organized and functioning in a different way. The children's ombudsman institution in Poland is regulated by the Constitution. In Belgium, Greece, Spain, Norway, Romania, France, Croatia, Sweden, etc., the institution is founded by virtue of a law or some other act adopted by the Parliament. In some of the countries - Belgium, 
Austria, Norway, Russia - they are established as fully independent institutions, while in others - Greece, Spain, Romania - they have the status and rank of deputy ombudsmen.

The first specialized ombudsman for children’s rights defense was established in year 1981 in Norway (Law № 5 from March 6, 1981 on the Children's Ombudsman (as amended from July 17, 1998)). The obligations are to foster children's interests with regard to the public and private bodies and to monitor the development of conditions for children growing up. The Ombudsman can act on their own initiative or upon request by other people. They themselves judge if a request filed with them contains sufficient grounds to undertake actions.

In Sweden - the native land of the ombudsman's institution - the children have had their own ombudsman since 1993. The major function of the ombudsman is to defend minor persons' rights and interests (The Children's Ombudsman Act, Swedish Code of statutes no: 1993:335). For the young people's rights and interests to attract attention someone has to speak on their behalf and take care of their interests. They are engaged in all the cases where children happen to be in problem situations and they can intervene in the event of divorce, parental rights disputes, and any other cases of abuse.

A necessary condition for the work of the children's ombudsman is their constant contact with young people in order to be able to see life through their eyes. For this purpose, the office has introduced a help line for children up to 18 years. Thus, children can provide information, express their opinion and respectively request the intervention of the child ombudsman. This is one of the ways for children to receive information about their rights and about the work of the ombudsman. Based on its activities, the ombudsman forms opinions and is entitled with the power to propose amendments of laws and other measures for the improvement of young people's status.

The Children's Ombudsman exercises its powers in four areas: working with children up to 12 years old, with children between 13 and 18 years old, social problems and child safety and social planning. Within the institution, there is a council of 12 experts who support activities. The Council has an advisory function; it gives opinion on various issues and problems that relate to the work of the institution as a whole.

In Greece it is the ombudsman who has undertaken the mission to defend and foster children's rights. For the protection of children's rights the ombudsman is entitled with powers in issues related to individuals, natural persons or legal entities violating children’s rights (Law № 3094, January 22, 2003 on the Ombudsman, art. 3). The ombudsman is assisted by five deputy ombudsmen and one of them is appointed a deputy ombudsman for children's rights. The ombudsman exercises competence with regard to the public sector, local authorities and local self-government bodies, private municipal and state enterprises.

To ensure the protection of children's rights, the Ombudsman may make a motivated request in writing to the person cited in the complaint to provide the necessary documents and other evidence. The person cannot refuse to provide information with the argument that it is classified. The Ombudsman must protect the personal and professional secrecy of individuals and must not publish information which would identify them (Law № 3094, January 22, 2003 for the Ombudsman, art. 4, item 5). Upon refusal to provide such evidence, the Ombudsman may request the assistance of the public authorities, professional associations, judicial authorities and the cooperation of the prosecution.

In Poland the institution of children's rights ombudsman is constitutionally regulated (The Constitution of the Republic of Poland of 2nd April, 1997). The Constitution of the Republic of Poland proclaims that it is a state priority to ensure the defense of children's rights and interests. The powers, competence and procedure of appointment of a Commissioner for children's rights are regulated by a law (Children's Ombudsman Act of January 6,2000 ). The ombudsman is independent from other state authorities in his actions and is responsible only before the Sejm.

The Children's ombudsman undertakes measures to secure full and harmonic development of children with the due respect for their dignity and honour. The major directions of his activities are stipulated by the Law on the children's ombudsman that puts a particular focus on: the right of healthy life, the right of family upbringing, the right of adequate social conditions, and the right of education. The Ombudsman is the one undertaking the needed actions for the defense of children against violence, cruelty, exploitation, depravity, neglect and ill-treatment.

This institution in Denmark was established on July 1, 1994 upon the initiative of non-governmental organizations and natural persons (Regulation № 2 of January 5, 1998 of the Minister for social policy, in implementation of Law № 453 of June 10, 1997). The minister for social policy established a National Council for Children working to ensure children's rights and respectively their defense. The Council assesses the 
conditions of life of children in Denmark in accordance with the UN Convention on the rights of the child.

The Council has the following functions: to evaluate and determine the conditions of social development, which could potentially have an adverse effect on the ability of children to develop; to establish cases in the legislation and administrative practice when the children's needs and their rights are not respected sufficiently or are violated and treated incorrectly or inappropriately; provides information about children; give rise to debates on relevant issues by defending the children's rights in public debates, and besides that it also works on giving children good opportunities to participate in the public debate and to have influence on the development in society.

In France such a Service was established by virtue of the law of March 6, 2000 (Law № 2000-196 of March 6, 2000). The defender receives individual petitions by children themselves or by parents of children whose rights were not respected or defended. The children's defender has large powers in providing the implementation of the national and international legal standards related to children. He is empowered to consider individual petitions and signals of violated rights and to issue recommendations for the improvement of their protection, to propose amendments of legislation and to influence the public opinion to the direction of recognition and respect of children's rights and interests.

In Austria within the period 1989 to 1995 nine federal ombudsmen were established for the defense of the children's and youths rights (Federal law on the child's well-being, 1989). Their structure, financing, responsibilities and functions vary in the different provinces, but in all of them the ombudsmen are established as an independent state institution and nobody can interfere with their activities. The ombudsmen have a large scope of competences. They defend children's interests in court and administrative proceedings, influence public opinion through the media and public debates and provide information on the children's well-being and their interests. The Ombudsman institutions cooperate in the preparation of opinions on the current legislation and on draft legislative acts related to the rights of children and adolescents.

In Spain the ombudsman institutions for protection of children's rights were established by law in Madrid in 1996 and Catalonia in 1989. The ombudsman for child protection in Madrid exercises the following powers: supervising the activities of state and private institutions of child's protection, receiving and handling complaints with regard to situations that can be dangerous and harmful to children, providing information and carrying out consultations, making proposals for changes in laws and procedures to improve the protection of children's rights, formulating proposals, warnings and recommendations, pursuing a policy of informing children and parents about their rights, problems and needs.

In Catalonia, the Ombudsman is empowered to supervise the activities of the administrative authorities of the autonomous community. The ombudsman for children's rights has the following powers: offering interpretations of regulations and of amendments thereto, developing and proposing changes in the procedures as well as the substantive rules in order to improve the state of children's rights.

In Iceland, the institution was established in 1995. The Ombudsman endeavors to ensure that the rights, needs and interests of children are duly taken into consideration by the public authorities, individuals, organizations and their representatives. In its work the ombudsman can give directions and make proposals to support the interests of children in all spheres of life (Law on Children's Ombudsman 83/94, art. 3).

The Ombudsman has a leading role in discussions on the establishment of a policy on issues about children in the public. It proposes measures to improve laws and regulations concerning children. The Ombudsman takes action within its powers when it thinks that the rights, needs and interests of children in the society have been violated by actions or lack of actions of a public authority, an individual or an organization or their representative.

Evidence for significance and importance of the institution specialized ombudsman for children's rights is the European Network of Ombudspersons for Children (ENOC, website, 2015). This is an international organization of independent national human rights institutions within the protection of the child, established in 1997 in the town of Trondheim, Norway. It comprises 44 independent organizations working in the field on the protection of children's rights from 35 countries in Europe.

\section{Bulgarian Ombudsman}

In Bulgaria the changes in the Law on the Ombudsman (Ombudsman Act, Prom. SG. 48 of 23.05.2003, effective from 1.01.2004 amend. SG. 15 of 15.02.2013, effective from 1.01.2014), the National Ombudsman was assigned a legal mandate and specific powers to protect the rights of the child. The institution already has the responsibility not only to rule on individual complaints and signals which affect the rights or interests of the 
child, to carry out inspection measures on its own initiative, where it finds that the necessary conditions for their protection are not met, but also to monitor general situation of the children's rights, to encourage institutions to comply with them, to guarantee that their actions will be consistent with the national and international standards established by national legislation and international treaties to which Bulgaria is a party, and to take actions for the promotion of children's rights. It has the right to speak on behalf of the child and in their defense (Annual Report of the Ombudsman of the Republic of Bulgaria in 2012).

The ombudsman exercises control on the activities of the protection authorities, specialized facilities for children, education system, health system, social sphere and local self-government and undertakes actions on his own initiative upon establishing that children's rights are threatened or that there are no adequate conditions created for their defense.

The Ombudsman's activity in this field is based on the Constitution of the Republic of Bulgaria, the laws of the country, the UN Convention on the Rights of the Child, its protocols and all international instruments to which Bulgaria is a party (Annual Report of the Ombudsman of the Republic of Bulgaria in 2010).

Most signals are by parents and relatives of the child, followed by citizens and non-governmental organisations. The least are the complaints filed by the child, but there is an increase in the number of cases in which the Ombudsman is turned to by young people over the age of majority and who left the institutions for children. There is a tendency for increase in the number of complaints in the field of children's rights in 2014. This is a sign that there are areas of society concerning the rights and interests of the child, which require more efficient legal solutions and working mechanisms for promotion of best practices (Annual Report of the Ombudsman of the Republic of Bulgaria in 2014).

\section{Conclusion}

The comparative legal analysis clears that the Children's Rights Ombudsman is emerging as an effective mechanism for protection of the rights and interests of children. The Ombudsman was established as an independent institution that complements the existing remedies for the protection of children's rights and interests. It protects the rights, freedoms and legitimate interests of children as defined in the Convention and the Universal Declaration of Human Rights. The main task of the Ombudsman is disseminating information on children's rights under the Convention, and analysis of the current situation on the protection of children's rights and interests in the country. Precisely the Children's Rights Ombudsman is one that can protect them from exploitation, cruelty and indifference on the part of the society as they are the most unprotected and vulnerable social group, and the children are our future.

\section{References}

Annual Report of the Ombudsman of the Republic of Bulgaria in 2010, Retrieved from http://www.ombudsman.bg/reports/1135

Annual Report of the Ombudsman of the Republic of Bulgaria in 2012. Retrieved from http://www.ombudsman.bg/pictures/FINAL\%20DOKLAD\%202012.pdf

Annual Report of the Ombudsman of the Republic of Bulgaria in 2014. Retrieved from http://www.ombudsman.bg/pictures/annual\%20report\%202014.pdf

European Network of Ombudspersons for Children. Retrieved from https://www.crin.org/en/enoc

Flekkoy, M. G. (1990). Working for the rights of children: The experience of the Norwegian ombudsman for children. Florence: UNICEF.

\section{Copyrights}

Copyright for this article is retained by the author(s), with first publication rights granted to the journal.

This is an open-access article distributed under the terms and conditions of the Creative Commons Attribution license (http://creativecommons.org/licenses/by/3.0/). 